\title{
Międzynarodowa pozycja Nowej Zelandii jako mocarstwa regionalnego
}

owa Zelandia geograficznie położona jest na obszarze południowego
Pacyfiku, zlokalizowanym w obrębie Oceanii. Jest to region pod wieloma względami unikatowy w skali globalnej, charakteryzuje się bowiem niespotykanym gdziekolwiek indziej stopniem rozproszenia tworzących go podmiotów państwowych i quasi-państwowych ${ }^{1}$, a także ich zróżnicowaniem pod względem terytorialno-demograficznym, gospodarczo-handlowym, kulturowym i etnicznym.

W przeszłości o kształcie jego międzynarodowego środowiska w znacznym stopniu decydowała formalna dominacja szeregu mocarstw ${ }^{2}$, jako że region ten przez długi okres znajdował się w obrębie imperiów kolonialnych państw europejskich, aby następnie zostać objętym systemem powierniczym funkcjonującym pod auspicjami $\mathrm{ONZ}^{3}$. W ostatnich dziesięcioleciach doświadczył on jednak istotnych zmian, sprawiających iż wiele

Ze względów czysto praktycznych w dalszej części wszystkie podmioty położone na południowo-wschodnim Pacyfiku określane będą mianem państw, bez względu na ich prawno-międzynarodowy status.

Na temat mocarstwowości formalnej zob. A. Włodkowska, Mocarstwowość w polityce zagranicznej, [w:] Wstęp do teorii polityki zagranicznej państwa, red. R. Zięba, s. 167.

Za atrybuty polityki mocarstwowej dominację, prymat, hegemonię oraz sfery wpływów, interesów i odpowiedzialności uznaje m.in. Hedley Bull. Zob. H. Bull, The Anarchical Society. A Study of Order in World Politics, New York 202, s. 207-218. 
z tworzących go podmiotów zyskało polityczną niezależność i związaną z tym możliwość samodzielnego kształtowania własnych stosunków zewnętrznych zarówno pomiędzy sobą nawzajem, jak i z dawnymi mocarstwami. W wyniku zmian zachodzących również w innych częściach świata przeobrażeniu uległa także pozycja dawnych mocarstw kolonialnych i powierniczych, w tym zarządzającej częścią terytoriów pacyficznych Nowej Zelandii ${ }^{4}$.

Zmiany te zmniejszyły zakres dominacji formalnej, nie przyczyniły się jednak do całkowitego zaniku obecności dawnych mocarstw na tymże obszarze, a także jej faktycznego aspektu ${ }^{5}$. W przypadku państw europejskich i Stanów Zjednoczonych jest to uwarunkowane głównie więzami natury historycznej i kulturowej, w przypadku zaś Nowej Zelandii podobnie jak Australii - faktem iż sama położona jest na południowym Pacyfiku, region ten stanowi więc dla niej najbliższe sąsiedztwo. Zasadniczym celem niniejszego artykułu jest wobec tego próba analizy obecnej pozycji Nowej Zelandii w regionie i udzielenie odpowiedzi na pytanie czy obecny kształt środowiska międzynarodowego południowego Pacyfiku, a także relacje pomiędzy rządem $w$ Wellington oraz władzami pozostałych państw sprawiają, iż kraj ten zajmuje pozycję mocarstwa regionalnego. W próbie odpowiedzi na powyższe pytanie ograniczymy się jednak wyłącznie do okresu od 2000 r., a także relacji Nowej Zelandii z podmiotami - podobnie jak ona sama - posiadającymi status członka regionalnej instytucji integracyjnej jaką jest Forum Wysp Pacyfiku ${ }^{6}$.

\section{Teoretyczna perspektywa badawcza}

Mocarstwowość danego aktora międzynarodowego nieodłącznie związana jest z kwestią jego relatywnej potęgi, czyli pewnej przewagi posiadanej nad innymi podmiotami, do których jest on przyrównywany ${ }^{7}$. Zagadnienie to w stosunkach międzynarodowych uznawane jest za istot-

4 Dotyczyło to Samoa Zachodniego do 1962 r. (terytorium powiernicze ONZ), Wysp Cooka do 1965 r. (terytorium zależne), Nauru do 1968 r. (terytorium powiernicze ONZ zarządzane wspólnie z Australią i Wielką Brytanią) i Niue do 1974 r. (terytorium zależne). Na temat mocarstwowości faktycznej zob A. Włodkowska, s. 167-168.

Grono to - oprócz nowej Zelandii - obejmuje Australię, Fidżi, Kiribati, Nauru, Niue, Tonga, Wyspy Salomona, Wyspy Cooka, Wyspy Marshalla, Sfederowane Stany Mikronezji (SSM), Tuvalu, Vanuatu, Palau, Papuę Nową Gwineę (PNG) i Samoa (dawniej Samoa Zachodnie).

7 W języku angielskim, będącym dominującym językiem teorii stosunków międzynarodowych, pojęcia mocarstwa i potęgi są wręcz synonimami. 
ne do tego stopnia, iż niektórzy badacze w osobie chociażby Hansa J. Morgenthaua twierdzili wręcz, iż politykę międzynarodową należy traktować wyłącznie $\mathrm{w}$ kategoriach przeciwstawianych sobie potęg $\mathrm{w}$ walce o supremację i przetrwanie ${ }^{8}$. Pomimo zainteresowania kwestią potęgi liczne próby podejmowane w celu wskazania czym ona jest i jak należy ją analizować nie doprowadziły jednak do uzgodnienia jednego wspólnego stanowiska w tym zakresie. Potęga wciąż interpretowana jest na różne niekiedy przeciwstawne wobec siebie - sposoby, które Jeffrey Hart dzieli na trzy główne nurty - utożsamiające ją z: kontrolą nad zasobami, aktorami lub też rezultatami działań ${ }^{9}$, które w istotnie możemy ograniczyć do dwóch podejść traktujących potęgę jako miarę zasobów warunkujących możliwości działania, bądź też same efekty działań.

Rozbieżności w podejściu do potęgi wynikają przede wszystkim z faktu, iż dostęp do określonych fizycznych zasobów wpływa w określonym stopniu na zdolność państw do działania w sferze międzynarodowej, ich skutki nie są jednak od tychże zasobów wprost zależne. Sytuacja ta określana mianem paradoksu niezrealizowanej potęgi - skłania znaczną część badaczy do rozróżnienia pomiędzy typem potęgi odnoszącym się stricte do samych zasobów i kolejnym dotyczącym wyłącznie skutków ich posiadania, które Klaus Knorr określa odpowiednio jako potęgę przypuszczalną (putative power) i urzeczywistnioną (actualized) ${ }^{10}$. Autor ten zakłada, iż istnieje pewien stały zestaw zasobów, który można traktować jako ogólny wyznacznik siły ${ }^{11}$ danego państwa, poddany następnie procesowi konwersji determinuje skuteczność jego działań. Nie podejmuje Knorr jednak kwestii przyczyn tegoż zjawiska, czy też jego przebiegu ${ }^{12}$.

Paradoks niezrealizowanej potęgi staje się również istotnym punktem rozważań Davida Baldwina podejmującego się zadania, którego Knorr nie realizuje. Baldwin konieczność konwersji potęgi potencjalnej (poten-

H. J. Morgenthau, Scientific Man vs. Power Politics, Chicago 1946, s. 71.

Zob. J. Hart, Three Approaches to the Measurement of Power in International Relations, "International Organization" 1976, Vol. 30, No. 2, s. 289-303.

Podobnego rozróżnienia dokonują m.in. Ch. Kindleberger - siła (strenght) i potęga (power) - M. Ash - siła (force) i potęga (power) - oraz D. A. Baldwin - potęga potencjalna (potential power) i faktyczna (actual power). Zob. K. Knorr, The Power of Nations: The Political Economy of International Relations, New York, 1975, s. 9; Ch. P. Kindleberger, Power and Money, New York 1970, s. 56; M. A. Ash, The Analysis of Power with Special Reference to International Politics, „World Politics” 1951, Vol. 3, No. 2, s. 218-220; D. A. Baldwin, Power Analysis In World Politics: New Trends versus Old Tendencies, „World Politics" 1979, Vol. 31, No. 2, s. 163.

11 W dalszej części terminy potęgi i siły stosowane będą zamiennie.

12 K. Knorr, The Power of Nations..., s. 9-10. 
tial power), w potęgę faktyczną (actual power) wiąże ze zróżnicowaniem samych zasobów pod względem sfery, w której występują (militarna, polityczna, ekonomiczna itd.), ich skali (broń konwencjonalna, nuklearna itd.), a także wzajemną niewymienialnością jednego zasobu na inny. Niezrealizowanie potęgi - twierdzi - wynika więc z błędnych przypuszczeń, iż zasoby siłowe użyteczne w pewnych sytuacjach, będą takie również we wszystkich pozostałych. Wbrew temu poglądowi - zdaniem Baldwina -poszczególne zasoby mogą zostać wykorzystane wyłącznie w określonych okolicznościach do realizacji konkretnych działań, nie sposób ich również wymieniać na inne, za pomocą jakiegoś wspólnego zamiennika, w postaci np. pieniądza ${ }^{13}$.

Baldwin postuluje dalej, zaproponowaną przez Harolda D. Lasswella i Abrahama Kaplana, kontekstualną analizę potęgi, polegającą na ograniczeniu przedmiotu poznania wyłącznie do samych praktyk państwowych w konkretnych sytuacjach wobec każdego innego aktora z osobna ${ }^{14}$. Nie rozwiązuje zatem paradoksu niezrealizowanej potęgi, lecz pomija go poprzez całkowite ignorowanie zasobów siłowych. Zdając sobie jednak sprawę z nieskończonej wręcz liczby możliwych permutacji, jakie rodzi jego metoda, powstających z nałożenia na siebie trzech zmiennych - nadawcy i odbiorcy oddziaływań oraz okoliczności, w których mają one miejsce - powołując się na Harolda i Margaret Sprout, opowiada się za analizą wyłącznie sytuacji najbardziej prawdopodobnych, stanowiących swoiste twarde jądro (hard core) relacji ${ }^{15}$.

Zgoła odmienne stanowisko zajmuje natomiast Ray S. Cline, dla którego zasoby siłowe są punktem wyjścia do dalszej analizy. Twierdzi on bowiem, iż paradoks niezrealizowanej potęgi wynika przede wszystkim z niepełnego ich wykorzystania, jest więc skutkiem braku umiejętności lub też woli. Proponuje zatem metodę liczenia potęgi polegającą na modyfikacji wielkości puli zasobów o czynniki jakościowe w postaci dwóch zmiennych - strategii i woli jej realizacji. Swój model przedstawia w postaci matematycznego równania:

$\mathrm{Pp}=(\mathrm{C}+\mathrm{E}+\mathrm{M}) \times(\mathrm{S}+\mathrm{W})$, gdzie:

$\mathrm{Pp}$ - potęga postrzegana (perceveived power)

C - masa krytyczna (critical mass)

E - możliwości ekonomiczne (economic capability)

M - możliwości wojskowe (military capability)

D. A. Baldwin, Power Analysis..., s. 164-167.

Tamże, s 167, H. D. Lasswell, A. Kaplan, Power and Society, New Haven 1950, s. 85-94.

15 D. A. Baldwin, Power Analysis..., s. 167; H. Sprout, M. Sprout, Toward a Politics of the Planet Earth, New York 1971, s. 178. 
S - strategia (strategic purpose)

W - wola urzeczywistnienia strategii (will to pursue national strategy $)^{16}$

We wzorze powyższym masę krytyczną sprowadza Cline do wielkości terytorium danego państwa i liczby jego ludności. Możliwości wojskowe obejmują natomiast wielkość sił zbrojnych, ekonomiczne zaś mierzone są za pomocą popularnych wskaźników makroekonomicznych: produktu krajowego brutto (PKB), wielkości obrotów handlu zagranicznego i PKB per capita. Przy próbie kwantyfikacji strategii, będącej - zdaniem Cline'a - właśnie umiejętnością przekształcania zasobów ${ }^{17}$ oraz woli jej realizacji napotyka autor na większe trudności. Stosuje przy tym dość niedoskonałą metodę polegającą na przypisaniu każdej z nich wartości w postaci jedynki lub też ułamka dziesiętnego, wyznaczanych w oparciu o opinie ekspertów zajmujących się polityką danego państwa ${ }^{18}$.

Oba zaprezentowane podejścia posiadają pewne niedoskonałości, które jednak można przynajmniej w pewnym stopniu wyeliminować poprzez ich połączenie. W przypadku ujęcia Baldwina za jego istotną wadę uznać należy przede wszystkim jego zbytni redukcjonizm. Autor ów dość drobiazgowo dokonuje rozróżnienia pomiędzy poszczególnymi zasobami oddzielając np. jeden typ uzbrojenia od innego i traktując je jako pojedyncze, niewymienialne środki możliwe do zastosowania jedynie w ściśle określonych sytuacjach. Baldwin zakłada ponadto, iż analiza relacji przez pryzmat ścierających się w nich potęg powinna wyjaśniać rezultat każdego najmniejszego zdarzenia. Wówczas badacz skłonny byłby rozpatrywać nie tyle rozstrzygnięcie całego konfliktu pomiędzy dwoma stronami (w którym przecież rozmaite zasoby znajdują zastosowanie), co każdą pojedynczą potyczkę stanowiącą jego część. Wydaje się jednak, iż rozwiązaniem dogodniejszym okazuje się w tym zakresie całościowe podejście do mających miejsce pomiędzy danymi aktorami procesów, nie zaś jednostkowe rozpatrywanie poszczególnych tworzących je zdarzeń.

W ujęciu Cline'a natomiast potęga danego aktora jest w znacznym stopniu uzależniona od subiektywnej oceny wystawionej jego strategii i woli jej realizacji. Ta zaś dokonywana jest przez inną osobę $\mathrm{w}$ odniesie-

16 R. S. Cline, The Power of Nations in the 1990s. A Strategic Assessment, Lanham 1994, s. 27-29. Po raz pierwszy metoda ta została przedstawiona przez Cline'a w pracy World Power Assesment: A Calculatus of Strategic Drift, Boulder 1975.

17 J. Caporaso umiejętność tę traktuje jako jedyny wyznacznik potęgi państwowej. Zob. J. A. Caporaso, Dependence, Dependency, and Power in the Global System: A Structural and Behavioral Analysis, ,International Organization” 1978, Vol. 32, No. 1, s. 31. 
niu do każdego z państw, a zatem z zastosowaniem rozmaitych, nie zawsze pokrywających się ze sobą kryteriów. Ponadto wydaje się, iż część równania odnosząca się do samych zasobów powinna obejmować wyłącznie te spośród nich, które mogą posłużyć jako środek w polityce międzynarodowej. Za takie z pewnością nie uchodzą jednak ani terytorium państwowe, ani też liczba ludności. Ponadto potencjał militarny wypadałoby rozwinąć o element jakościowy, odzwierciedlający choć w pewnym stopniu poziom wyszkolenia i uzbrojenie wojsk. Możliwości ekonomiczne warto również połączyć z komponentem społecznym, a także wyłączyć z nich handel zagraniczny, będący raczej sposobem wykorzystania produktu krajowego brutto, aniżeli zasobem sensu stricto.

Zastosowane w dalszej części artykułu podejście będzie zatem połączeniem analizy relatywnego nowozelandzkiego potencjału w sferze militarnej i ekonomiczno-społecznej oraz działań przedstawiających formy i skalę wykorzystania poszczególnych zasobów w polityce zagranicznej, kierowanej wobec pozostałych państw regionu. Porównanie potencjałów militarnych poszczególnych państw dokonane zostanie w wyniku połączenia dwóch syntetycznych wskaźników - liczebności armii i wielkości wydatków wojskowych na osobę - stanowiących wspólnie o zdolnościach bojowych danej armii. W układzie takim pierwszy składnik determinuje skalę działań jakich dane siły zbrojne mogą się podjąć, drugi natomiast warunkuje poziom wyszkolenia i - przede wszystkim - uzbrojenia, wpływa zatem na zakres wykorzystania wojsk. Analiza potencjału gospodarczo-społeczny dokonana zostanie za pomocą czterech wskaźników: produktu krajowego brutto (PKB), będącego podstawowym miernikiem wielkości gospodarki danego państwa, oczekiwanej długości życia noworodków, PKB per capita, a także stopnia alfabetyzacji osób powyżej 15 roku życia. Trzy ostatnie spośród wymienionych miar łącznie tworzą oenzetowski wskaźnik rozwoju społecznego, tutaj jednak zostaną przedstawione w sposób oddzielny z uwagi na niedostępność pewnych danych w odniesieniu do niektórych państw regionu.

\section{Potencjał militarny i jego wykorzystanie}

Specyfika regionu południowego Pacyfiku sprawia, iż większość znajdujących się w jego obrębie państw nie utrzymuje stałych sił zbrojnych ${ }^{19}$. Podmioty te dysponują określonym potencjałem ludnościowym

\footnotetext{
19 Zob. Central Intelligence Agency, The World Factbook, https://www.cia.gov/library/ publications/the-world-factbook/index.html [dostęp: 22.08.2010].
} 
i zasobami uzbrojenia, pozwalającymi - w wypadku zaistnienia wymagających tego okoliczności - na sformowanie przynajmniej niewielkich oddziałów uzbrojonej milicji, brak stałych struktur armijnych, odpowiednich procedur i wyspecjalizowanej kadry skłania jednak ku twierdzeniu, iż ich potencjał militarny jest bliski zeru. Oddziały te ponadto - jak się wydaje - mogą zostać użyte wyłącznie w celu obrony terytorium narodowego, nie stanowią więc instrumentu, za pomocą którego dysponujące nimi rządy mogłyby kształtować własne otoczenie międzynarodowe. Dlatego też w dalszej części skupimy się jedynie na zdolnościach militarnych państw, które regularne siły zbrojne posiadają tj. Australii, Nowej Zelandii, Papui Nowej Gwinei, Fidżi i Tonga.

Przedstawione w tabeli 1 statystyki wskazują, iż Nowa Zelandia jest drugą siłą militarną w regionie, zarówno pod względem liczebności wojsk, jak i poziomu ich dofinansowania. Biorąc pod uwagę obie z przyjętych miar góruje ona dość wyraźnie nad armiami Fidżi, Tonga i Papui Nowej Gwinei, niemniej dystrybucja potencjału militarnego w obrębie regionu świadczy o jego sporej koncentracji, jako że znaczna jego większość znajduje się w posiadaniu jednego tylko państwa - Australii.

Tabela 1. Podstawowe wskaźniki potencjału militarnego państw regionu (2010)

\begin{tabular}{|c|c|c|}
\cline { 3 - 3 } Państwo & $\begin{array}{c}\text { Żołnierze } \\
\text { w służbie czynnej }\end{array}$ & $\begin{array}{c}\text { Wydatki wojskowe na osobę - } \\
\text { tys. USD }\end{array}$ \\
\hline Australia & 57500 & 622,43 \\
\hline Nowa Zelandia & 9836 & 137,96 \\
\hline Fidżi & 3500 & 17,37 \\
\hline PNG & 3100 & 39,74 \\
\hline Tonga & 500 & 5,42 \\
\hline
\end{tabular}

Źródło: opracowanie własne na podstawie danych CIA, amerykańskiego Departamentu Stanu, australijskiego Departamentu Spraw Zagranicznych i Handlu oraz Nowozelandzkich Sił Obronnych.

Pomimo niewielkich rozmiarów Nowozelandzkie Siły Obronne realizują dość ambitne cele postawione przed nimi przez rząd w Wellington, obejmujące:

- obronę terytorium Nowej Zelandii;

- realizację zobowiązań sojuszniczych wobec Australii, w postaci bliskiego partnerstwa w kwestiach obronności; 
- wspieranie pokoju na południowym Pacyfiku poprzez reagowanie na pojawiające się zagrożenia dla stabilności wewnętrznej i bezpieczeństwa znajdujących się na obszarze tym państw i terytoriów;

- partycypację w utrzymywaniu bezpieczeństwa w regionie Azji i Pacyfiku;

- wspieranie bezpieczeństwa globalnego poprzez udział w operacjach pokojowych i humanitarnych pod auspicjami ONZ i innych wielostronnych inicjatywach ${ }^{20}$.

Działając w oparciu o powyższe cele siły nowozelandzkie są w ostatnich latach niezwykle aktywne na arenie międzynarodowej, przede wszystkim w odniesieniu do operacji typu peacekeeping i peacemaking. Obecnie biorą udział w 14 misjach zagranicznych w 10 różnych krajach, przeznaczając na ich poczet sporą jak na własne możliwości liczbę 710 żołnierzy ${ }^{21}$. Co więcej - jak podaje amerykański Departamentu Stanu - w szczytowym okresie konfliktu w Timorze Wschodnim, w jednej tylko operacji INTERFET, udział brało ok. 10\% ogółu nowozelandzkich wojsk ${ }^{22}$, dzięki czemu kontyngent ten stanowił drugi - po australijskim - najliczniejszy spośród 22 kontyngentów narodowych partycypujących w misji ${ }^{23}$.

Najistotniejsze z punktu widzenia postawionego w artykule tym celu uczestnictwo w regionalnym systemie bezpieczeństwa południowego Pacyfiku polega w głównej mierze na dwojakiego rodzaju działaniach stałej ochronie niektórych terytoriów obcych przed wszelką agresją z zewnątrz oraz doraźnej pomocy wojskowej udzielanej na wyraźne życzenie innego państwa. Są to więc wyłącznie działania typu defensywnego, realizowane $\mathrm{w}$ celu zachowania regionalnego status quo.

Zgodnie z uchwalonymi przez parlament w Wellington aktami konstytucyjnymi terytoriów z stowarzyszonych z Nową Zelandią - Niue

${ }^{20}$ Zob. Report of the New Zealand Defence Force for the year ended 30 June 2003, s. 13, http://www.nzdf.mil.nz/downloads/pdf/public-docs/nzdf_03.pdf [dostęp: 22.08.2010] oraz raporty za lata kolejne dostępne pod adresem http://www.nzdf.mil.nz/publicdocuments/annual-report/default.htm.

${ }^{21}$ Obecnie wojska nowozelandzkie stacjonują w Afganistanie, Timorze Wschodnim, Egipcie, Syrii, Izraelu, Libanie Sudanie, Iraku, Korei Południowej, na Wyspach Salomona i na terytorium Antarktydy. Zob. New Zealand Defence Force. NZDF Deployments, http://www.nzdf.mil.nz/operations/deployments/default.htm [dostęp: 22.08.2010].

22 U. S. Department of State, Background Note: New Zealand, http://www.state.gov/r/ pa/ei/bgn/35852.htm [dostęp: 22.08.2010].

23 D. Horner, Making the Australian Defence Force, t. 4, Melbourne 2001, s. 9. 
z 1974 r. ${ }^{24}$ oraz Wysp Cooka z 1965 r. $^{25}$ - Nowozelandzkie Siły Obronne odpowiadają bezpośrednio za kwestię ich bezpieczeństwa, podobnie jak czynią to w przypadku samej Nowej Zelandii. Państwa te nie posiadają własnych sił zbrojnych, dlatego też gwarancja ich nienaruszalności terytorialnej i samorządności spoczywa całkowicie w gestii Nowej Zelandii, której lotnictwo i marynarka wojenna prowadzi stałe patrole wód terytorialnych i wyłącznych stref ekonomicznych Niue i Wysp Cooka, w wypadku zaistnienia takiej potrzeby, na prośbę zainteresowanego rządu, podejmuje natomiast interwencję zbrojną ${ }^{26}$. Warto w tym miejscu zaznaczyć, iż analogiczne zadania w odniesieniu do szeregu innych terytoriów w regionie realizują również Australia i Francja oraz - przede wszystkim Stany Zjednoczone.

W ostatniej dekadzie Nowozelandzkie Siły Obronne obok armii australijskiej, stanowiły również podstawowy instrument reagowania na pojawiające się $\mathrm{w}$ regionie kryzysy wewnętrzne, albowiem uczestniczyły w obu realizowanych w okresie tym misjach stabilizacyjnych - w Królestwie Tonga i na Wyspach Salomona.

Interwencja jaką $\mathrm{w}$ listopadzie $2006 \mathrm{r}$. podjęto $\mathrm{w}$ stolicy Tonga Nuku'alofie - miała charakter zakrojonego na niewielka skalę działania ad hoc spowodowanego nagłym wybuchem zamieszek, sprowokowanych decyzją parlamentu o odroczeniu demokratycznych reform, które sprawiły iż rząd tego państwa poczuł się zmuszony do proszenia o pomoc z zewnątrz. Reakcja jaką w odpowiedzi podjęły rządy nowozelandzki i australijski okazała się niezwykle szybka i skuteczna, jako że już następnego dnia po wystosowaniu prośby w stolicy kraju wylądował wspólny kontyngent wojskowo-policyjny liczący łącznie 110 żołnierzy (w tym 60 nowozelandzkich) i 45 policjantów. Wsparcie to sprawiło, iż już kolejnego dnia po przybyciu misji rząd Tonga podjął decyzję o zniesieniu części z wprowadzonych wcześniej ograniczeń związanych ze stanem wyjątkowym, po dwóch tygodniach natomiast przybyły kontyngent można było całkowicie wycofać ${ }^{27}$.

${ }^{24}$ Niue Constitution Act 1974, http://www.paclii.org/nu/legis/num_act/ca1974188/ [dostęp 22.08.2010].

25 Cook Islands Constitution Act 1964, http://www.legislation.govt.nz/act/public/1964/0069/latest/DLM354069.html [dostęp:: 22.08.2010].

${ }^{26}$ New Zealand Ministry of Foreign Affairs and Trade, http://www.mfat.govt.nz/Countries/Pacific/Niue.php [dostęp: 22.08.2010].

${ }^{27}$ Szerzej na temat konfliktu zob: NZ, Aust troops land in Tonga, TVNZ, http://tvnz.co.nz/ view/page/411424/895213; A. Pohiva, Tongan Government Refused to Listen to People, http://archives.pireport.org/archive/2007/January/01-23-comm1.htm; U.S. Depart- 
Konflikt jaki dotknął Wyspy Salomona miał natomiast charakter bardziej długotrwały i przewlekły wymagał zatem innego typu działań. Jego początków można doszukiwać się już w 1978 r. kiedy wyspy te uzyskały niepodległość ${ }^{28}$. Trwające od momentu tego napięcia pomiędzy dwiema zamieszkującymi archipelag grupami - Guales i Malaitans - przybrały postać regularnych walk dopiero jednak w 1998 r. Doprowadziły wówczas do całkowitej destabilizacji politycznej kraju, czego przejawem było m.in. porwanie urzędującego premiera w 2000 r. ${ }^{29}$ Trzy lata później, 21 lipca, zmusiły natomiast parlament do przyjęcia aktu o umożliwieniu realizacji pomocy zagranicznej ${ }^{30}$, otwierającego drogę do podjęcia działań stabilizacyjnych przez wielonarodowy kontyngent wojskowy w ramach regionalnego mechanizmu bezpieczeństwa $w$ oparciu o deklarację biketawską ${ }^{31}$. Już trzy dni później na największej z wysp archipelagu - Guadalcanal - wylądował wojskowy komponent w ramach Regionalnej Misji Wsparcia dla Wysp Salomona (RAMSI), który pozostaje tam do dnia dzisiejszego. Początkowo tworzyło go ok. 1800 żołnierzy wywodzących się z pięciu państw regionu, w większości Australijczyków, którzy również objęli jego dowództwo. W jego skład wchodziły także oddziały nowozelandzkie w postaci kompanii piechoty, kompanii wojsk inżynieryjnych i oddziału helikopterów transportowych. Cały korpus wojskowy miał odgrywać główną rolę przede wszystkim w początkowej fazie misji, której rozciągłość w czasie szacowano na okres sześciu miesięcy. Stawiane przed nim zadania w większości zrealizowano do marca 2004 r., co stało się przyczyną zmniejszenia ilości personelu wojskowego do ok. 700 żołnierzy, do końca 2004 r. natomiast ich liczba spadła do zaledwie $60^{32}$. Z kolei do dnia

ment of State, Background Note: Tonga, http://www.state.gov/r/pa/ei/bgn/16092. htm [dostęp: 22.08.2010]. Islands 1998-2004, Canberra 2004.

${ }^{29}$ Szerzej na temat konfliktu zob. R. W. Glenn, Counterinsurgency in a Test Tube. Analyzing the Success of the Regional Assistance Mission to Solomon Islands (RAMSI), Santa Monica 2007, s. 11-42; Politics and State Building in Solomon Islands, red. S. Dinnen, S. Firth, Canberra 2008, 39-94.

30 Zob. Facilitation of International Assistance Act 2003, http://www.paclii.org/sb/legis/ num_act/foiaa2003386/ [dostęp: 22.08.2010].

31 Zob. „Biketawa” Declaration, http://www.forumsec.org.fj/resources/uploads/attachments/documents/Biketawa\%20Declaration,\%2028\%200ctober\%2020002.pdf [dostęp: 22.08.2010].

32 Zob. R. W. Glenn, s. 20, 35-36; New Zealand Defence Force. Overseas Operations. Solomon Islands, http://www.nzdf.mil.nz/operations/deployments/solomon-islands/ faq/default.htm [dostęp" 22.08.2010]. 
dzisiejszego na terytorium Wysp Salomona pozostaje ok. 200 żołnierzy sił pokojowych, w tym 43 Nowozelandczyków ${ }^{33}$.

Działalność nowozelandzkich sił zbrojnych w okresie ostatniego dziesięciolecia dowodzi zatem przede wszystkim, iż potencjał militarny jaki sobą reprezentują jest rzeczywiście wykorzystywany. Zapisy o ich udziale $\mathrm{w}$ działaniach wspierających pokój i bezpieczeństwo w regionie nie pozostają jedynie na papierze, albowiem wojska te brały udział we wszystkich realizowanych w tym okresie misjach mających cel ten urzeczywistniać. Szybkość i skuteczność interwencji w Tonga i na Wyspach Salomona wskazują natomiast, iż są to siły dobrze zorganizowane i mobilne, a tym samym zdolne do realizacji stawianych przed nimi zadań. Wkład Nowej Zelandii w funkcjonowanie regionalnego systemu bezpieczeństwa był jak dotąd z pewnością większy aniżeli większości państw południowego Pacyfiku oraz krajów spoza regionu. Wyjątek w tym zakresie stanowi jedynie Australia bez udziału której - jak się wydaje - realizacja jakiejkolwiek regionalnej misji wymagającej sformowania liczniejszego kontyngentu i prowadzenia operacji przez dłuższy okres czasu jest niemożliwa.

\section{Potencjał gospodarczo-społeczny i jego wykorzystanie}

Dane dotyczące potencjału gospodarczego przedstawione w tabeli 2 - podobnie jak w przypadku możliwości wojskowych - wskazują na wyraźną dominację dwóch państw - Australii i Nowej Zelandii - w tym wypadku jednak występujące dysproporcje przybierają jeszcze większą skalę. Druga w zestawieniu tym Nowa Zelandia kolejny raz dość znacznie ustępuje najsilniejszej gospodarczo Australii, wielkość jej PKB stanowi jednak niemal dwudziestokrotność wartości analogicznego wskaźnika trzeciej w zestawieniu tym Papui Nowej Gwinei.

W odniesieniu do potencjału społecznego dość wyraźna dominacja Australii i Nowej Zelandii dotyczy jedynie zamożności obywateli. Dysproporcja w kwestii przewidywanej długości życia noworodków jest również zauważalna, choć nie tak znaczna, wartości trzeciego wskaźnika - stopnia alfabetyzacji - pozwalają natomiast mówić o osiągnięciu ich poziomu także przez szereg innych państw. Relacje te występują również w odniesieniu do samej rywalizacji nowozelandzko-australijskiej, gdzie dostrzec można identyczny z opisanym powyżej trend.

33 Regional Assistance Mission to Solomon Islands, New Zealand Fact Sheet, http://www. ramsi.org/files/cn/nz_fact_sheet.pdf [dostęp: 22.08.2010]. 
Tabela 2. Podstawowe wskaźniki potencjału ekonomiczno-społecznego państw regionu

\begin{tabular}{|c|c|c|c|c|}
\hline Państwo & $\begin{array}{l}\text { PKB wg. cen } \\
\text { bieżących - } \\
\text { mln USD } \\
(2006)\end{array}$ & $\begin{array}{l}\text { Oczekiwana } \\
\text { długość życia } \\
\text { noworodków } \\
(2008)\end{array}$ & $\begin{array}{c}\text { PKB } \\
\text { per capita- } \\
\text { USD (2008) }\end{array}$ & $\begin{array}{c}\text { Stopień alfa- } \\
\text { betyzacji osób } \\
\text { powyżej } 15 \text { roku } \\
\text { życia (2008) }\end{array}$ \\
\hline Australia & 784500 & 81,6 & 48253 & $99 \%$ \\
\hline Fidżi & 3100 & 70,7 & 4264 & $93,7 \%$ \\
\hline Kiribati & 110 & 63,2 & 804 & $\mathrm{~b} / \mathrm{d}$ \\
\hline Nauru & 26 & 64,2 & 2396 & $\mathrm{~b} / \mathrm{d}$ \\
\hline Niue & 13 & $\mathrm{~b} / \mathrm{d}$ & $\mathrm{b} / \mathrm{d}$ & $95 \%$ \\
\hline Nowa Zelandia & 107700 & 80,4 & 29879 & $99 \%$ \\
\hline Palau & 157 & 71,2 & 8812 & $92 \%$ \\
\hline PNG & 5500 & 66,3 & 1218 & $57,3 \%$ \\
\hline Samoa & 455 & 71,9 & 2988 & $99,7 \%$ \\
\hline SSM & 237 & 70,9 & 2154 & $89 \%$ \\
\hline Tonga & 295 & 73,3 & 2891 & $98,9 \%$ \\
\hline Tuvalu & 31 & 69,3 & 3213 & $\mathrm{~b} / \mathrm{d}$ \\
\hline Vanuatu & 452 & 64,0 & 2388 & $74 \%$ \\
\hline Wyspy Cooka & 180 & 74,2 & 10907 & $95 \%$ \\
\hline Wyspy Marshalla & 144 & 71,2 & 2737 & $93,7 \%$ \\
\hline Wyspy Salomona & 457 & 73,7 & 1284 & $76,6 \%$ \\
\hline
\end{tabular}

Źródło: opracowanie własne na podstawie danych Departamentu Statystyki ONZ, CIA oraz australijskiego Departamentu Spraw Zagranicznych i Handlu.

Wykorzystanie w polityce międzynarodowej dysproporcji dotyczących wielkości PKB przyjmować może szereg form, przede wszystkim polega jednak na manipulacji wielkością obrotów handlowych i dostarczaniu pomocy zagranicznej $j^{34}$. Stosowanie środków ekonomicznych w sposób pozytywny, np. poprzez preferencyjne reguły handlowe, przy-

34 W kwestii klasyfikacji ekonomicznych środków i metod polityki zagranicznej zob. min. I. Popiuk-Rysińska, Środki i metody polityki zagranicznej, [w:] Polityka zagraniczna państwa, red. J. Kukułka, R. Zięba, Warszawa 1992, s. 85-87. 
nosi państwom wobec których są one wykorzystywane określone korzyści gospodarcze i społeczne, umożliwia zatem wywieranie wpływu na ich sytuację wewnętrzną. Działanie odwrotne pozbawia natomiast korzyści tych ich dotychczasowych beneficjentów, pozwala więc na wymuszanie określonych zachowañ ${ }^{35}$. Staje się to możliwe wówczas gdy regularność interakcji, w połączeniu z ich skalą prowadzi do pewnego stopnia uzależnienia jednych państw od drugich, czy też ich obustronnej współzależności $^{36}$. Ponadto promocja własnych towarów i usług w innych krajach stanowi element ekspansji kulturowej, a zatem należałoby rozumieć ją jako soft power w ujęciu Josepha S. Nye'a Jr. ${ }^{37}$.

Ekonomiczna polityka Nowej Zelandii w odniesieniu do innych państw regionu pozwala wysunąć wniosek, iż przede wszystkim stosuje ona środki ekonomiczne o charakterze pozytywnym, unika zaś wszelkich form ich negatywnego wykorzystania ${ }^{38}$. Analiza danych dotyczących handlu w obrębie regionu przedstawionych w tabeli 3 wskazuje, iż - obok Stanów Zjednoczonych, Australii, Singapuru i Japonii - jest ona jednym z głównych eksporterów towarów i usług do pozostałych państw regionu. Zgoła inaczej kształtuje się jednak kwestia handlu w przeciwną stronę, albowiem dla większości państw tych nie stanowi ona istotnego celu eksportowego. Przyczyną tego jest fakt, iż wszyscy - z wyjątkiem Australii regionalni partnerzy handlowi Nowej Zelandii nie korzystają ze szczególnie preferencyjnego dostępu do jej rynków. Kwestie te niezmiennie od 30 lat podlegają zapisom porozumienia SPARCETA, na mocy którego Nowa Zelandia zapewnia niemal wszystkim towarom z państw tych wolny od ceł $\mathrm{i}$ barier pozataryfowych dostęp do własnego rynku ${ }^{39}$. Upływ czasu od momentu sygnowania umowy, w połączeniu z generalnym trendem w ekonomicznej polityce zagranicznej rządu w Wellington do całkowite-

35 Tamże, s. 85-87; K. J. Holsti, International Politics. A Framework for Analysis, London 1974, s. 240-268.

36 W kwestii relacji pomiędzy potęgą a współzależnością warto wskazać przede wszystkim klasyczną już pozycję Roberta O. Keohane'a i Josepha S. Nye'a Jr. Power and Interdependence, New York 2001, s. 9-16.

Zob. w szczególności J. S. Nye Jr., Bound to Lead: Changing Nature of American Power, New York 1990; tenże, The Powers to Lead, Oxford 2008.

38 Władze nowozelandzkie stosują sankcje ekonomiczne jako negatywny środek oddziaływania ekonomicznego tylko wówczas, gdy działanie takie jest od nich wymagane w wyniku przyjęcia stosownej rezolucji przez Radę Bezpieczeństwa ONZ. Zob. New Zealand Ministry of Foreign Affairs and Trade http://www.mfat.govt.nz/Foreign-Relations/Pacific/0-Fiji-FAQ.php [dostęp: 22.08.2010].

39 South Pacific Regional Trade and Economic Cooperation Agreement (SPARTECA), http://www.worldtradelaw.net/fta/agreements/spartecafta.pdf. 
go uwalniania własnego handlu ze wszystkimi partnerami od wszelkich ograniczeń, sprawiły jednak, iż warunki zawarte w porozumieniu SPARCETA nie są w chwili obecnej preferencyjne. Towary z państw objętych jego zapisami muszą zatem $\mathrm{w}$ większym stopniu niż miało to miejsce w 1980 r. rywalizować z tymi pochodzącymi z pozostałych krajów.

Tabela 3. Główni partnerzy handlowi państw regionu (2005)

\begin{tabular}{|c|cc|c|}
\hline Państwo & Partnerzy - eksport & Partnerzy - import \\
\hline $\begin{array}{c}\text { Australia } \\
(2009)\end{array}$ & $\begin{array}{c}\text { 1. Chiny (22\%), 2. Japonia (20\%), } \\
\text { 3. Korea Pd. (8\%) }\end{array}$ & $\begin{array}{c}\text { 1. Chiny (18\%), 2. USA (11\%), } \\
\text { 3. Japonia (8\%) }\end{array}$ \\
\hline Fidżi & $\begin{array}{c}\text { 1. USA (19\%), 2. Australia (17\%), } \\
\text { 3. Wielka Brytania (12\%) }\end{array}$ & $\begin{array}{c}\text { 1. Singapur (27\%), 2. Australia } \\
\text { (24\%), 3. Nowa Zelandia (19\%) }\end{array}$ \\
\hline Kiribati & $\begin{array}{c}\text { 1. USA (26\%), 2. Belgia (25\%), } \\
\text { 3.Japonia (16\%) }\end{array}$ & $\begin{array}{c}\text { 1. Australia (34\%), 2. Fidżi (28\%), } \\
\text { 3. Japonia (18\%) }\end{array}$ \\
\hline Nauru & 1. RPA (57\%), 2. Indie (15\%), & 1. Australia (63\%), 2. USA (10\%), \\
\hline Niue & 3. Kanada (6\%) & 3. Niemcy (8\%)
\end{tabular}

Źródło: Pacific Regional Trade and Economic Cooperation. Joint Baseline and Gap Analysis oraz australijski Departament Spraw Zagranicznych i Handlu. 
Rząd w Wellington dąży jednak do zmiany tego stanu rzeczy, czego pierwszym przejawem było zawarcie $\mathrm{w}$ sierpniu $2001 \mathrm{r}$. porozumienia PACER, sygnowanego przez wszystkich członków Forum Wysp Pacyfiku. W dokumencie tym strony zobowiązały się do stopniowej integracji własnych gospodarek w celu wzmocnienia regionalnego handlu i - w dłuższej perspektywie - stworzenia wspólnego regionalnego rynku, w związku z czym zakładano podjęcie w przyszłości rozmów dotyczących nowych porozumień o preferencyjnych warunkach handlowych ${ }^{40}$. Pierwszą tego typu umową było zawarte wraz PACER porozumienie PICTA obejmujące jednak wyłącznie kwestie handlu towarami pomiędzy wszystkimi członkami Forum z wyjątkiem Australii i Nowej Zelandii ${ }^{41}$. Współpracę gospodarczą pomiędzy obydwoma z wspomnianych krajów reguluje natomiast już od 1983 r. seria porozumień o bliższych stosunkach ekonomicznych (Closer Economic Relations - CER $)^{42}$. Obecnie zaś trwają rozmowy na temat rozciągnięcia postanowień PICTA również na usługi, a także - od sierpnia 2009 r. - zawarcia porozumienia PACER Plus zakładającego integrację gospodarczą również pomiędzy Australią i Nową Zelandią a pozostałymi krajami regionu, które pozwoliłoby na zamknięcie prawnych ram integracji gospodarczej regionu.

Istotnym elementem relacji Nowej Zelandii z pozostałymi - z wyjątkiem Australii - państwami regionu jest również pomoc zagraniczna. Kwestia wspierania zrównoważonego rozwoju gospodarczego, redukowania ubóstwa i zwiększania stabilności wewnętrznej poprzez działania oddolne jest dla regionu tego niezwykle istotna, albowiem sześć z wchodzących w jego skład państw zaliczanych jest przez ONZ do grona krajów najmniej rozwiniętych, wszystkie zaś (z wyjątkiem Nowej Zelandii i Australii) do krajów rozwijających się położonych na małych wyspach ${ }^{43}$. Dlatego też na obszarze tym, aktywność pomocową prowadzi znaczna część państw wysokorozwiniętych i podmiotów instytucjonalnych.

40 Pacific Agreement on Closer Economic Relations (PACER), http://www.forumsec.org. fj/resources/uploads/attachments/documents/PACER.pdf [dostęp 22.08.2010].

${ }^{41}$ Pacific Island Countries Trade Agreement (PICTA), http://www.forumsec.org.fj/resources/uploads/attachments/documents/PICTA.pdf (dostęp 22.08.2010).

42 Pełna lista porozumień tworzących CER dostępna jest na stronach Departamentu Spraw Zagranicznych i Handlu australijskiego rządu pod adresem http://www.dfat. gov.au/geo/new_zealand/anz_cer/anz_cer.html [dostęp: 22.08.2010].

43 Pełna lista państw dostępna jest na witrynie internetowej Wysokiego Przedstawiciela ds. Krajów Słabo Rozwiniętych, Krajów Rozwijających się Pozbawionych Dostępu do Morza i Krajów Rozwijających się Położonych na Małych Wyspach. Zob. UN-OHRLLS, http://www.unohrlls.org/en/home/ [dostęp: 22.08.2010]. 
Rozmiary oficjalnej pomocy rozwojowej (ODA) udzielanej przez rząd w Wellington za pośrednictwem Nowozelandzkiej Agencji ds. Międzynarodowej Pomocy i Rozwoju (NZAID), podobnie jak w przypadku wielu innych wysoko rozwiniętych krajów, nie spełniają wymogu relacji wobec dochodu narodowego brutto (DNB) na poziomie $0,7 \%$ DNB, ustalonego na mocy rezolucji ONZ nr 2626 z $1970 \mathrm{r}^{44}$ Osiągana w ostatnich latach wielkość wsparcia w granicach $0,3 \% \mathrm{DNB}^{45}$, krytykowana jest zarówno na forum międzynarodowym, jak i w samej Nowej Zelandii, niemniej brakuje woli politycznej, aby w najbliższych latach dokonać jakichś istotnych zmian w tym zakresie.

Tabela 4. Główne źródła oficjalnej pomocy rozwojowej dla państw regionu (2004-2008)

\begin{tabular}{|c|c|c|}
\hline Dawca pomocy & Wielkoś pomocy - mln USD & $\begin{array}{c}\text { Udział w ogólnej } \\
\text { sumie pomocy }\end{array}$ \\
\hline Australia & 2580,39 & $55,2 \%$ \\
\hline USA & 836,39 & $17,89 \%$ \\
\hline Nowa Zelandia & 372,89 & $7,98 \%$ \\
\hline $\begin{array}{c}\text { Wspólnota } \\
\text { Europejska }\end{array}$ & 310,55 & $6,64 \%$ \\
\hline Japonia & 265,04 & $5,67 \%$ \\
\hline
\end{tabular}

Źródło: opracowanie własne na podstawie danych OECD.

W odniesieniu do regionu południowego Pacyfiku efekt jaki mógłby stać się konsekwencją niewielkich rozmiarów pomocy w relacji do DNB jest jednak w pewnym stopniu niwelowany, w związku z faktem, iż ponad połowa nowozelandzkiej ODA kierowana jest na ten właśnie obszar ${ }^{46}$. Dążenia do koncentracji pomocy zgodnie z oficjalnymi stanowiskami wynikają przede wszystkim z poczucia historycznych, geograficznych i kulturowych więzi łączących Nową Zelandię z innymi państwami regio-

${ }^{44}$ Zob. International Development Strategy for the Second United Nations Development Decade, http://daccess-dds-ny.un.org/doc/RESOLUTION/GEN/NR0/348/91/ IMG/NR034891.pdf?OpenElement [dostęp p: 22.08.2010].

${ }^{45}$ Zob. DAC Members' Commitments and Performance: Summary Table of OECD Secretariat Projections, http://www.oecd.org/dataoecd/17/12/44981982.pdf [dostęp: 22.08.2010].

46 Zob. New Zealand's Development Assistance in the Pacific, http://www.nzaid.govt.nz/ library/docs/factsheet-pacific-overview.pdf [dostęp 22.08.2010]. 
nu, powodującymi jej szczególne zainteresowanie i odpowiedzialność za dobrobyt krajów stanowiących wszakże jej najbliższe sąsiedztwo. Trudno jednak nie dostrzegać faktu, iż rozwój gospodarek pozostałych państw regionu, przyczyniający się do wzrostu ich zdolności handlowych, w połączeniu ze zwiększeniem poziomu stabilności wewnętrznej, wpływającej korzystnie na bezpieczeństwo realizowanych na ich obszarze bezpośrednich inwestycji zagranicznych powoduje również wymierne korzyści dla samej Nowej Zelandii. Działania takie sprawiają, że - pomimo iż ogólna suma przeznaczana przez rząd na pomoc zagraniczną jest relatywnie niewielka - kraj ten jest jednym z głównych dawców pomocy dla południowego Pacyfiku, co przedstawiono $w$ tabeli 4. Pozycję lidera również i w tym zakresie zajmuje Australia, na drugiej pozycji znajdują się natomiast Stany Zjednoczone, przy czym - w przypadku tych ostatnich - jest to wynikiem nie tyle szczególnego ich zaangażowania na tym obszarze, co faktu iż ogólna pula środków przeznaczanych przez nie na pomoc rozwojową znacznie przewyższa wkład większości krajów świata. Nowa Zelandia plasuje się natomiast na pozycji trzeciej wyprzedzając znacznie zamożniejsze od siebie Wspólnotę Europejską i Japonię.

Trzy pozostałe z przytoczonych w tabeli 2 wskaźników stanowią z kolei uproszczony miernik atrakcyjności społecznej danego kraju, będącej wynikiem zarówno nakładów finansowych jak i rozwiązań instytucjonalno-organizacyjno-prawnych. Wydaje się iż skutkiem wystąpienia dysproporcji tego typu, a wiec również sposobem oddziaływania za ich pomocą, mogą być przynajmniej dwa zjawiska tj. imitacja rozwiązań występujących w państwie uznawanym za bardziej rozwinięte, jako próba skopiowania przyczyn jego sukcesu; lub też migracja ludności do krajów bardziej rozwiniętych, aby w ten sposób skorzystać z dostępnego w nich dobrobytu społecznego. Z uwagi na ograniczenia jakim podlega każdy artykuł, w dalszej części pominiemy jednak analizę prób przeniesienia na własny grunt rozwiązań nowozelandzkich przez pozostałe z państw, skupimy się natomiast na imigracji.

Dane dotyczące potencjałów społecznych wskazują, iż Nowa Zelandia okazuje się atrakcyjnym miejscem osiedlenia dla mieszkańców wszystkich pozostałych państw regionu z wyjątkiem Australijczyków. Wydaje się również iż podstawowym motywem kierującym osobami decydującymi się na migrację jest czynnik materialny. W tabeli 5 przedstawiono dane na temat głównych punktów docelowych emigracji z państw regionu w okresie pięciolecia 2004-2008. Zestawienie to nie obejmuje jednak obywateli Nowej Zelandii, jako że kwestia atrakcyjności społecznej innych państw dla jej mieszkańców nie jest przedmiotem naszego zain- 
teresowania, a także Australijczyków dla których Nowa Zelandia nie jest państwem społecznie bardziej atrakcyjnym niż ich kraj macierzysty.

Tabela 5. Główne kierunki emigracji państw regionu (2004-2008)

\begin{tabular}{|c|c|c|}
\hline Państwo docelowe & Liczba emigrantów & $\begin{array}{c}\text { Udział w ogøle liczby } \\
\text { emigrantów }\end{array}$ \\
\hline Nowa Zelandia $^{*}$ & 30529 & $\mathbf{5 0 , 8 7 \%}$ \\
\hline Australia & 12003 & $20 \%$ \\
\hline USA & 11444 & $19,07 \%$ \\
\hline Japonia & 2126 & $3,54 \%$ \\
\hline Niemcy & 1857 & $3,09 \%$ \\
\hline
\end{tabular}

dane dotyczące Nowej Zelandii nie obejmują mieszkańców Niue i Wysp Cooka, którzy - z uwagi na fakt, iż posiadają obywatelstwo nowozelandzkie - maja prawo do wolnego dostępu na jej terytorium i nie figurują w statystykach imigracyjnych Źródło: opracowanie własne na podstawie danych OECD.

Z powyższych danych wynika, iż Nowa Zelandia jest najpopularniejszym punktem docelowym migracji z pozostałych krajów regionu, ponad dwukrotnie wyprzedzając inne wysoko rozwinięte społecznie państwa tj. Australia i Stany Zjednoczone. Należy przy tym zaznaczyć, iż polityka imigracyjna rządu w Wellington nie należy do liberalnych, izolacja geograficzna wynikająca z wyspiarskiego położenia kraju pozwala natomiast w znacznym stopniu minimalizować skalę imigracji nielegalnej. Polityka ta, regulowana przez akt imigracyjny z $1987 \mathrm{r}^{47}$, ukierunkowana jest przede wszystkim na uzupełnienie braków wykwalifikowanej siły roboczej na nowozelandzkim rynku pracy, a także sprowadzenie inwestorów zagranicznych. Dwie główne kategorie osób, którym przyznawane jest prawo stałego pobytu wraz z prawem do podjęcia zatrudnienia stanowią więc przedsiębiorcy pragnący rozpocząć działalność gospodarczą oraz tzw. wykwalifikowani migranci (skilled migrants), którym stosowna wiza udzielana jest po weryfikacji ich wykształcenia, doświadczenia zawo-

47 Akt ten zostanie wkrótce zastąpiony nowymi regulacjami wchodzącymi w życie 29.11.2010 r., którejednaknie wprowadzają zasadniczych zmian w polityce imigracyjnej. Zob Immigration Act 1987, http://www.legislation.govt.nz/act/public/1987/0074/ latest/DLM108018.html; Immigration Act 2009 http://www.legislation.govt.nz/act/ public/2009/0051/latest/DLM1440303.html [dostęp: 22.08.2010]. 
dowego, stanu zdrowia i znajomości języka angielskiego ${ }^{48}$. Osobną grupę tworzą również członkowie rodzin osób wchodzących w skład dwóch powyższych kategorii oraz uchodźcy ${ }^{49}$.

W stosunku do obywateli niektórych państw regionu rząd w Wellington stosuje pewne udogodnienia, sprawiające iż ich szanse na osiedlenie się w Nowej Zelandii rosną. Przede wszystkim dotyczy to mieszkańców Niue i Wysp Cooka, którym - z uwagi na fakt, iż posiadają obywatelstwo nowozelandzkie - przysługuje prawo swobodnego wjazdu na jej terytorium. Ponadto obywatele Kiribati, Tuvalu, Tonga i Samoa, oprócz normalnych procedur imigracyjnych, uczestniczyć mogą w loterii wiz na pobyt stały w ramach ustalonych dla każdego z państw tych rocznych kwot ${ }^{50}$. Wówczas nie muszą spełniać wymogów odnośnie do kwalifikacji zawodowych (wykształcenie, doświadczenie) stawianych migrantom wykwalifikowanym, konieczne jest jednak aby posiadali ofertę zatrudnienia w Nowej Zelandii.

Analiza zagranicznej polityki ekonomicznej Nowej Zelandii pozwala wysunąć wniosek, iż jej potencjał gospodarczy jest wykorzystywany jedynie w niewielkim stopniu, co uwidacznia się przede wszystkim w pozycji jaką zajmuje ona jako odbiorca towarów eksportowanych z pozostałych państw regionu. Nowozelandzkie PKB stanowi niemal dziesięciokrotność sumy PKB wszystkich - z wyjątkiem Australii - krajów południowego Pacyfiku, co daje jej możliwość odbioru znacznie większej aniżeli ma to miejsce obecnie ilości towarów i usług produkowanych na tymże obszarze. Wydaje się ponadto, iż także handel w przeciwną stronę mógłby ulec intensyfikacji. Sprzyja temu bliskość geograficzna będąca atutem w stosunku do podmiotów takich jak Stany Zjednoczone, konieczne jest jednak stworzenie ram prawnych, umożliwiających nawiązanie bliższych stosunków handlowych. Ich zręby powstały na mocy porozumienia PACER, konkretne regulacje są jednak nadal przedmiotem negocjacji. Podobnych

48 W każdym wypadku złożenie aplikacji o wizę wiąże się również z koniecznością uiszczenia odpowiedniej opłaty. W kwestii wymogów stawianych imigrantom wykwalifikowanym, ich rodzinom i inwestorom zob. Immigration New Zealand Operational Manual. Residence, http://www.immigration.govt.nz/NR/rdonlyres/DE3CE116-100F4855-A3C8-38413511E3CC/0/Residence.pdf [dostęp: 22.08.2010]. Nowa Zelandia przyjmuje rocznie do 300 uchodźców. Zob. Immigration New Zealand, Refugee Family Support Category, http://www.immigration.govt.nz/migrant/ stream/live/refugeefamilysupport/ [dostęp: 22.08.2010]. Pacific Access Category, http://www.immigration.govt.nz/migrant/stream/live/pacificaccess/; Immigration New Zealand, Samoan Quota 2010, http://www.immigration. govt.nz/migrant/stream/live/samoanquota/ [dostęp: 22.08.2010]. 
prób poprawienia własnej pozycji nie podejmuje rząd w Wellington w odniesieniu do pomocy zagranicznej, której wielkość zdaje się go satysfakcjonować. Plasuje ona Nową Zelandię w gronie głównych dawców wsparcia, pozostawią ją jednak znacznie w tyle przede wszystkim za Australią. Liczba napływających do Nowej Zelandii imigrantów z krajów południowego Pacyfiku stawiająca ją w pozycji zarówno przed Australią, jak i państwami spoza regionu stanowi natomiast przykład najpełniej wykorzystanych dysproporcji w regionalnej dystrybucji potencjałów.

\section{Wnioski}

Zarówno militarne, jak i gospodarczo-społeczne zasoby pozostające w dyspozycji rządu w Wellington pozwalają Nowej Zelandii dominować nad większością państw regionu, a jej przewaga w tym zakresie zapewnia jej szerokie możliwości oddziaływania na inne państwa, w szczególności za pomocą środków gospodarczych i społecznych. Niemniej dość znaczny dystans jaki dzieli ją od przodującej w regionie Australii w istotnym stopniu utrudnia jej zajmowanie pozycji regionalnego lidera.

Działalność rządu w Wellington zdaje się potwierdzać istnienie woli politycznej odgrywania kluczowej roli na południowym Pacyfiku, czego przejawem jest aktywne uczestnictwo w operacjach pokojowych realizowanych w ramach regionalnego systemu bezpieczeństwa, realizacja funkcji obronnej wobec państw trzecich, a także specjalne przepisy imigracyjne w stosunku od obywateli niektórych z państw. Skuteczność działań tego typu uwidacznia się przede wszystkim w statystykach imigracyjnych, w oparciu o które można uznać Nową Zelandię za kraj najatrakcyjniejszy jako miejsce osiedlenia się dla większości regionalnych emigrantów z państw dysponujących mniejszym potencjałem społecznym niż ona sama. Ocena skuteczności wykorzystania potencjału militarnego sprawia więcej trudności, gdyż jego zastosowanie uzależnione jest od pojawienia się okoliczności tego wymagających oraz skutków działań innych państw (głównie Australii). Niemniej, jak dotąd, Nowozelandzkie Siły Obronne sprostały wszystkim zadaniom postawionym przed nimi w ciągu ostatnich lat. Inaczej przedstawia się sytuacja w przypadku sfery gospodarczej, jako że w tym wypadku Nowa Zelandia rywalizować musi również z szeregiem państw spoza regionu. Jej obecna pozycja jest w związku z tym słabsza aniżeli w odniesieniu do innych kwestii, podejmowane są jednak kroki mające na celu jej poprawę.

Wydaje się zatem, iż Nowa Zelandia jest obecnie regionalnym mocarstwem wojskowym i - w szczególności - społecznym, posiadającym 
potencjał predestynujący ją do odgrywania analogicznej roli w sferze gospodarczej. Mocarstwowość społeczna jest w tym wypadku wynikiem indywidualnych działań przyczyniających się do skutecznego wykorzystania posiadanego potencjału, bliska współpraca wojskowa z Australią powoduje natomiast istnienie swoistego asymetrycznego mocarstwowego tandemu, w którym strona nowozelandzka odgrywa rolę uzupełniającą, czy też dopełniającą. 


\section{Abstract}

Located in the South Pacific, for many years New Zealand has been an important part of a great power concert taking place within the region. The post1945 process which had given independence and the right to self-government to various states and territories formerly administered by the great powers, allowed them to shape their external relations with other states autonomously, and thus rendered the position of formal dominance previously held by the great powers obsolete. This included also New Zealand whose international position at that time was highly conditioned by trusteeship responsibilities performed pursuant to a UN mandate.

Combining David A. Baldwin's contextual approach to power analysis with Ray S. Cline's resource-based power model, the author examines the presentday distribution of military and socio-economic potential within the South Pacific region and depicts the unilateral exercise of local preponderance by the Wellington government conducted in the last 10 years. He reaches a conclusion that, stemming either from individual actions conducive to an efficient exploitation of the social potential, or a close cooperative relationship with Australia, which gives rise to an asymmetrical great-power military tandem, in which the Wellington side plays a complementary role, New Zealand currently holds a position of a regional military and social power, whereas its capabilities predestine it obtain a similar status also with respect to economic matters. 